\title{
Delivery of Neurotrophin-3 to the Cochlea using Alginate Beads
}

\author{
*Farnoosh Noushi, †Rachael T. Richardson, †Jennifer Hardman, * $\dagger$ Graeme Clark, \\ and $\rightarrow$ Stephen O'Leary
}

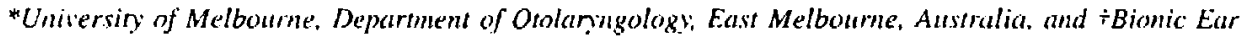
Insrisuse, East Melbourne, Australia.

Objective: The aim of this study was to design a novel cochlcar neturotrophin (NT) delivery system for the rescue of a) ditory neurons after ototoxicity-induced deafening.

Background: NT-3 is a trophic growth liktor that promotes the survival of the auditory nerve and may have a potential therapeutic rolc in slowing neuron loss in progressive deatness. cspecially as an adjunct to the current cochlear implant. Beads made from alginate are biodegradable, slow release substances that can be placed at the round window or inside the cochled. This study incestigated the loading properties. release kinetics. and implantation potential of alginate beads loaded with XT-3. Methods: Alginate beads wcre prepared using an ionic getation techniquic and postloaded with NT-3. Relcase of NT-3 was measured using enzyme-linked immunosorbent assay over 5 days. Alginale beads were implanted into dedfened guinea pigs for 28 dalys, after which survival of auditory neurons was assessed.
Results: Enzyme-linked immunosorbent assay studics demonstrited a $98 \%$ to $99 \%$ londing of NT-3 with a slow. partial relcase over 5 days in Ringer's solution. Furthernore, the addition of heparin to the delivery system modulated NT-3 release to a steudier pattem. Implantation of alginate-heparin beads in guineid pig cochlede produced minimal local tissue reaction. NT-3 loaded boads implanted at both the round window and within the sonia tympani of the basal turn provided auditory neurons signiticant protection from degradation and apoptosis compared with unloaded beads or untreated cochleae.

Conclusions: This study demonstrates alginate beads to he it safe, bicxlegradable and elfective delivery system for NT-3 to the cochlea. Key Words: Alginate-Cochlea-Drug JeliveryNeurotrophin-3-Sensorineural hearing loss. Orol Neurotol 26:528-533. 2005.
Localized drug delivery to the cuchlea is a promising method for the delivery of therapculic agents that may otherwise have toxic side cffects if administered systemically. One method of local delivery is diffusion of drugs though the semipermeable round window membranc. The round window is pernteable to various medications, which include gentamicin for the treatment of Menière's disease (1-4) and prednisolone for idiopathic sensorincural hearing loss (5-7). The potential benefits of round window delivery of drugs include a low systemic absorption and toxicity and the casc of delivery in the outpatient setting.

Techniques developed for round window drug de. livery have included blind transtympanic injections $(1,2)$. gelfoum (8). elvax-impregnated discs (9), transtympanic

Address correspondence and reprint requests to Siephien OLear: University of Mclbourne, Depanment of Oublaryngology. $32 \mathrm{Gisbome}$ Si. East Mlelboume, VIC 30()2. Australia: E-mail: sjolcary (â uninelb. cdu.au

Funding for this sludy was supplied by Royal Australasian College of Surgeons and the Siavros $S$. Niarchos Foundution. microcatheters $(3,4)$. and the microwick made of polyvinyl (10). However. many of the methods investiqated so far have limitations. Transtympanic delivery is limited by poor targeting and uncontrolled dose delivery. With the exception of gelfoam. most of the delivery systems are not biodegradable. Pump systems are limited by their cost and the requirement for hospitalization. - Dircet intracochlear delivery of drugs by way of pumps are an established experimental tool (11-15), but these systents are not suitable for humin usc becausc of the risk of introducing infection into the inner ear and the potential sequelac of meningitis.

We report a novel system for the delivery of drugs to the inner ear using a biodegradable and relatively inert agent, alginate-heparin beads. This system facilitates controlled and sustained drug delivery. Alginate as a delivery vehicle has been successfully used to encipsulate and deliver diverse bioactive growth factors (16) such as basic fibroblast growth lacror $(17,18)$, leukemia inhibitory factor (19), nerve growth factor (20), and ciliary neurotrophic factor (21). Furthemore, alginate has also been demonstrated to be an adequate nerve and 
cellular growth matrix (22-24). Heparin was also investigated as a suitable additive to our delivery system as a modulator for release of growth factors. Heparin hats bcen used to modulate relense of growth factors such as basic fibroblast growth factor, nerve growth factor, neurotrophin (NT)-3, and brain derived neurotrophic factor from fabricated matrices in a slow and controlled manner $(17,18,25-27)$.

In this study, we investigated the eflicacy of NT-3 relcase from alginate-heparin beads implanted on to the round window of guinea-pig cochleae. Auditory neurons degenerate and significant numbers undergo apoptosis after any cochlear pathology, resulting in the loss of hair cells. which includes most types of sensorineural hearing loss and ototoxic injuries. NTs have been shown to promote the survival of the auditory nerve in vitro $(28-35)$ and in vivo $(13,36,37)$. Because the optimal functioning of cochlear implants requires the preservation of this population of auditory neurons, there is interest in the potential therapeutic use of NTs, such as NT-3, as an adjunct to implantation. For this reason, we investigated the round window delivery of NTs becaluse this could potentially preserve the auditory neural population after deafness has occurred but before cochlear implantation.

Another potential therapcutic role for NT-3 is the prevention of ongoing apoptosis of auditory neurons after cochlear implantation. This could be achieved by the slow intracochlear release of NT-3 from polymers coating the cochlear electrodc. These electrodes are implanted into the basal turn of the cochlea (in a fluidfilled chamber known as the scala tympani). To determine whether this may be feasible, we also investigated whether alginate beads introduced into the scala tympani were effective in preventing degeneration of the auditory nerve.

\section{MATERIALS AND METHODS}

\section{Alginate Bead Production}

Alginate boads were prepared using an ionic gelation technique. Two percent $(w / v)$ sodium alginate (KolHV; ISP. Silverwater. NSW: Australia) with or withwut $1 \%(w / v)$ hepurin (Sigma-Aldrich. Cidstle IIill. NSW. Australia) was dissolved in MilliQ water and mixed ovemight until dissolved loming a gel-like solution. Subsequently. the gel was extruded through a 30 -gauge needle inte a bath of $0.1 \mathrm{M} \mathrm{CaCl}$ - precipitating calcium alginate spheres. The beads wore allowed to mature with gentle stiring for 20 minutes and ther washed three times over 30 to 40 minutes with $0.9 \%(w / v) ~ N a C l$. This method produced lurge beads in the order of 2 to $2.5 \mathrm{~mm}$. For in vivo experiments, a stream of high-pressurc $\mathrm{CO}_{3}$ was passed through the needle as the gel wals extruded, precipitating smaller $(0.5-1 \mathrm{~mm})$ alginate-heparin beads. The heads w'erc produced using slerile solutions and cquipment in a laminar how hood and finally ultraviolet irradiated for 30 minutes. All beads were made freslo for in vivo experiments with a colal dose of approximately $1.5 \mu \mathrm{g}$ of NT-3 for each "loaded bead" experiment (3).

\section{In Vitro NT-3 Release Studies}

Alginate and alginate-heparin beads were lested for loading and releuse of NT-3 in vitro using an enzyme-linked immunosorbent assily (ELISA). The aim was to produce the most effective loading and release profile for our delivery system. Beads with diameters of 2 to $2.5 \mathrm{~mm}$ ware loaded with human recombinant NT-3 (Chemicon, Boronia. Vic, Australia) by incubating the beads overnight at $37^{\circ} \mathrm{C}$ in Ringer's solution containing NT-3. Uptake of NT-3 was quantified by measuring the differences betwcen the initial and leftover londing solutions by a commercially available NT-3 ELISA kit (I'tomega, Annandale, NSW. Australia). After loading, the beads were then incubated in Ringer's solution at $37^{\circ} \mathrm{C}$, and eluants were sampled at regular intervils for up to 5 days to examine the release profile of NI-3 from the beads.

Three experiments were performed varying the amount of NT. 3 londed and the number of alginate and alginate-heparin beads. Each experiment varied in the number of bead and the conccitration of the load solution as derected in Table 1. All elution samples werc tested in triplicate measures to reduce error. The percentage of release for euch type of bead. in cach experinent, was calculated by dividin: the quantity relcased by the quantity of uptake. To increast the power of subsequent statistical analyses, the results of the three experiments uere combined.

\section{In Vivo Experimental Design}

The main measure of outeome was the density of SG.N, surviving after 4 weeks of treutment (NT-3 londed beads. unlouded beads, and untreated controls). SGNs degcnerute, and the majority undergo npoplosis after the loss of hair cells sustiuned during an ototoxic injury. Successful NT-3 delivery was inferred from an increase in the SCV density in NT-credted ears and compared with untreated ears.

Scren-day dealened adult pigmented guineu pigs ranging in weight from 650 wo 910 g were used for in vio experinkenty. Two methods of delivery of the beads were tested. round window and intraxcochlcar (Table 2). All contralareral cochlete were analy/ed as untrealed controls.

TABLE I. In ritro NT:3 releare studies

\begin{tabular}{|c|c|c|c|c|c|}
\hline $\begin{array}{c}\text { Fxperiment } \\
\text { no. }\end{array}$ & $\begin{array}{l}\text { Number of beuds } \\
\text { used in study }\end{array}$ & $\begin{array}{c}\text { NT-3 londing } \\
\text { concentration }(\mu g / m)\end{array}$ & $\begin{array}{l}\text { Loading: } \\
\text { volume }(\mu 1)\end{array}$ & $\begin{array}{l}\text { Uptakic } \\
\text { analysis }\end{array}$ & $\begin{array}{l}\text { Release analysts: } \\
\text { ELISA time intervils (days) }\end{array}$ \\
\hline 1 & 40 pain alginate & 1.3 .1 & 100 & No & $0.25,1,2,3,4.5$ \\
\hline$i$ & 40 alginate-heparin & 13.1 & 100 & No & $0.25,1,2.3 .4 .5$ \\
\hline 2 & 30 plain alginate & 5.94 & 200 & Yex & $0.25 .1,2,3,5$ \\
\hline 2 & 31) alginate-heparin & 5.94 & 200 & YLS & $0.25,1,2.3,4.5$ \\
\hline $3 a$ & 10 alginate-heparin & 30.5 & 100 & Yes & $0.25,1,2,3.4 .5$ \\
\hline $3 \mathrm{~h}$ & 10) alginate-heparin & 12.2 & 100 & Yes & $0,25,1,2,3,4,5$ \\
\hline
\end{tabular}

NT: neurotrophir: ELISA, enzyme linked immunosorbent assay. 
TABLF, 2. In vivo experiments

\begin{tabular}{llc}
\hline Bead plicenent & NT-3 loading & Guinea pigs \\
\hline Round window & Loaded beads & 5 \\
& Unloaded beads & 4 \\
Intracochlear & Loaded beads & 5 \\
& Unloaded beads & 4 \\
\hline
\end{tabular}

NT, neurorrophin.

\section{Guinea-Pig Anesthesia}

All surgical or auditory brainstem procedures werc conducted under anesthesia using an intramuscular injection of hetamine $(60 \mathrm{mg} / \mathrm{kg})$ and $x y l a z i n e(4 \mathrm{mg} / \mathrm{kg})$. Anesthetic was reversed with antisedan at $0.02100 .2 \mathrm{~m} / \mathrm{kg}$. For alginate bead implantation procedures, the animals were given a perioperative antibioric, baytril, and an additional analgesic, rimadyl ( $4 \mathrm{mg} / \mathrm{kg})$. All tocal skin infiltration was with $0.3 \mathrm{ml}$ of $2 \%$ lignocaine hydrochloride. All procedures and animal care was performed with the approva! and guidelines set by the Animul Rescarch and Ethics Committee of the Royal Victorian Eye and Ear Hospital.

\section{- Guinea-Pig Auditory Brainstem Responses and Deafening}

Hearing states of all pre- and postdeafened animals werc estimated from click-evoked auditory brainstem responses (ABR) (38). Pigmented guinea pigs with a click-cvoked ABR threshold of less than $48 \mathrm{~dB}$ peak-equivalent sound pressure level (normal hearing) wcre deafened by cannulation of the jugular vein or its large tributaries and delivery of furosemide (100 $\mathrm{mg} / \mathrm{kg}$ ) followed up by a subcutaneous injection of kanamycin sulphate $(400 \mathrm{mg} / \mathrm{kg}$ ) to produce a bilateral and symmetrical degencration of the cochlear scnsory epithelium (39) A postdealening $A B R$ was performed to confirm deafness. detined by a click-evoked ABR threshold of 93 dB peah equivalent sound prossure level or more. Animals not meeting this criterion were cxcluded tron the study,

\section{Alginatc Bead Implantation}

Scven days after deafening. the guinea pigs were implanted with either small loaded (approximately $1.5 \mu \mathrm{\mu t}$ of NT-3 per bead) or small unloaded bead. The bulla was approached dorsally and the round window visualized under the bony ridge of the facial nerve. For round window impluntation. the beads weic placed adjacent to the round window ( $\$ 5$ small beids) and sccured with a muscle/fascial graft. The scala tympani was implanted by perforating the round window, passing $f$ to 5 small beids into the hasal tum of the cochlea. and scaling the round window with a muscle gralt. Beads were implanted for 28 days

\section{Cochlear Processing and Histology}

Guinea pigs werc killed with an overdose of sodium pentoharbilone and perfused by way of the intracardiac roule with $0.9 \%(w / v)$ saline containing $0.3 \%(v / v)$ heparin sodium and $0.025 \%(\mathrm{w} / \mathrm{v})$ sodium nitrite followed up by $10 \%(\mathrm{v} / \mathrm{v})$ ncutral buftered formalin. The coschleas were removed and pustixed in $10 \%(v / v)$ neutral buffered formalin for a further 24 hours. The cochleac were then decalcificd in $4 \%(w / v)$ cthylcnedianinctetraacetic acid. For SGN density mcasurements, cochlease wcre cmbedded in paraffin and sectioned at $5 \mu \mathrm{m}$ arousd the round window and through the mid-modiolar plante. For histologic examination of cochleac around the implantation sitc, cochleate wcre embedded in resin and sectioned serially at $125 \mu \mathrm{m}$. All sections were staincd with hematoxylin-eosin.

\section{Data Analysis}

All histologic sections were analyzed for inflammatory and fibrotic changes, especially in the vicinity of the implanted beads. SGN densities of individual cochlear turns were counted using National Institute of Health Scion Inage analysis softwarc. Slides were blinded and randomized before counting, and three mid-modiolar sections were counted and averaged for each cochlea. For each section, SGN densities were analyzed for each modiolar turn.

All the data wcre cntered twice for consistency. MannWhitncy and Knuskal-Wallis nonparametric analysis of variance were used to test for differences in the in vitro NT-3 relcase study. One-way analysis of variance was used to test for the differences betwcen the three implantation groups (no treatment, round window beads, and intracochlear beads). Ninety-five percent confidence intervals are presented. Multiple comparison tests were also performed to identify which paired treatment was significant. Statistical analysis was performed using SPSS statistical software (V 8.0, Chicugo, IL. U.S.A.). $p<0,05$ was considered to be statistically significant.

\section{RESULTS}

Nr-3 relcase from alginate beads was cxamined in vitro and measured using ELISA. Three in vitro experiments were performed to evaluate the loading and releasc properties of plain alginate and alginate-heparin beads (Table 1). NT-3 loading profiles were evaluated from Experiments 2 and 3. These experiments revealcd a high uptake for plain alginate $(98.0 \%)$ and alginateheparin beads $(98.8 \%$ ) (Table 3$)$.

The release profile is demonstrated in Figure 1. There was no diflerence in tolal amount of release of NT-3 from the plain alginate or heparin-alginate beads over a 5-day period $(p=0.95$ ). The NT-3 detected, expressed as a percentage of initial uptake, over the 5 days was $0.33 \%$ for plain alginatc and $0.34 \%$ for alginate-heparin beads. However. there was a significant difference between the two beads in the release protile over the time period $(p=0.001)$. Plain alginate beads released the majority of the NT:3 in the first 6 hours $(94 \%$ of the total release over the 5 day period). whereas al ginate-heparin beads released NT-3 more slowly over the 5 days (Fig. 1).

TABLE 3. NT-3 uplake analwis

\begin{tabular}{|c|c|c|c|c|}
\hline $\begin{array}{c}\text { Experiment } \\
\text { no. }\end{array}$ & $\begin{array}{l}\text { Number of } \\
\text { beads used } \\
\text { for study }\end{array}$ & $\begin{array}{c}\text { NT-3 kand } \\
\text { concentration } \\
(\mu g / \mathrm{ml})\end{array}$ & $\begin{array}{l}\text { Postloaded } \\
\text { NT-3 } \\
\text { contentrution } \\
(\mu g / m l)\end{array}$ & $\begin{array}{l}\text { Percentage } \\
\text { NT-3 } \\
\text { uptake }\end{array}$ \\
\hline 2 & 35 pluin alginate & 5.94 & 0.119 & 98.0 \\
\hline 2 & 35 alginate-heparin & 5.94 & 0.043 & 99.3 \\
\hline 3 & 20) alginate-heparin & 30.5 & 0.494 & 984 \\
\hline 3 & 20 alginate-heparin & 12.2 & 0.161 & 98.7 \\
\hline
\end{tabular}

NT. neurolrophin. 


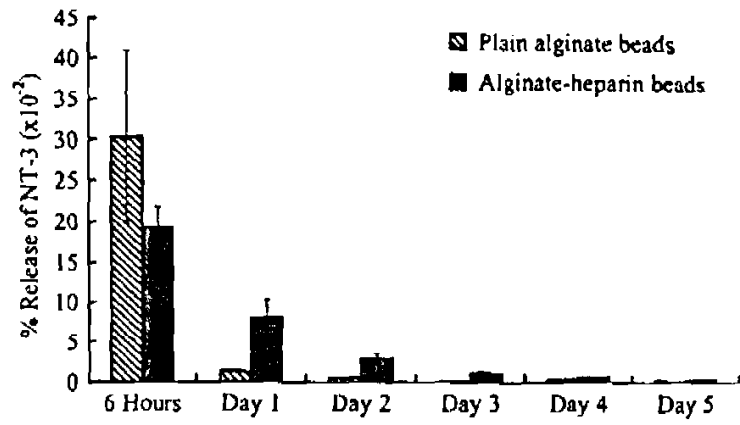

FIG. 1. Release of NT-3 from plain alginate or alginate-heparin beads. Plain alginate or alginate-heparin beads were loaded with NT-3 and placed in Ringer's solution, which was monltored for release of NT-3 by ELISA over 5 days. There was a significant difference $(\rho=0.001)$ in the release profile between the two groups, with the alginate-heparin beads demonstrating a steadier and slower release than the plain alginate beads. Release is expressed as a percentage of NT-3 taken up by the beads during loading. Error bars represent standard error of the mean.

\section{Histologic Analysis of Alginate Beads In Vivo}

Macroscopic examination of the inner ear al 4 weeks showed that the beads had lost some of their morphologic shape and degraded into a gelatinous paste. The round window and basal cochlcar turn were analyzed histologically for evidence of local tissue reaction to the beads. Hematoxylin-cosin stained sections revealed no significant tissue inflammation or fibrosis. Furthermore, no remnants of the beads were detected; however. this may have been a result of tissue processing.

In Vivo Results of NT.3 Loaded Alginate beads Spiral ganglion cells of all deafcned animals, including those treated with NT-3, exhibited cells with a range of histopathologic states, from apparently normal to pyknotic cells, some of which lacked nuclei. The critcrion for a therapeutic effect of the NT-3 was an increase in the density of spiral ganglion cells. Only ncurons with a clearly defined nucleus werc considered to be potentially viable and counted. Mid-modiolar spiral ganglion cell density measurements were made from both the round window and the intracochlear bead groups. The densitics from each cochlear turn wert measured in triplicate and subsequently alveraged. Midmodiolar SGN density measurcments were averaned across all the mid-modiolar turns of the cochlea, and comparisons were made for each of the individual experimental groups (Table 4).

In both the round window and intracochlear implantation sites. cochlcate troated with alginate beads loaded with NT-3 had grcater SGN survival than untreated or cochleae implanted with unloaded beads (Fig. 2). There was no signilicant difference in SGN densities between the unloaded and untreated contralateral ears.

In the round window group, a significantly higher $S G N$ density difference was observed in the NT-3 loaded beads $(p<0.001$, mean $=1,060, \mathrm{SD}=120)$ compared
TABLE 4. Combined mid-modiolar SGN densiry results

\begin{tabular}{|c|c|c|c|c|c|c|}
\hline & \multicolumn{2}{|c|}{ Round windous } & \multicolumn{2}{|c|}{ Intracochlear } & \multicolumn{2}{|c|}{ Combinced } \\
\hline & Mean & $95 \% \mathrm{CI}$ & Mean & $95 \% \mathrm{Cl}$ & мёал & $95 \% \mathrm{CI}$ \\
\hline Untreated & - & - & - & - & $7 \overline{770}$ & $(728,812)$ \\
\hline $\begin{array}{l}\text { Unloaded } \\
\text { beads }\end{array}$ & 686 & $(603,770)$ & 702 & $(985.821)$ & 69.5 & $(628,762)$ \\
\hline $\begin{array}{c}\text { Loaded } \\
\text { bends }\end{array}$ & 1.060( & $1.0019 .1 .112)$ & 984 & $(899,1,069)$ & 1023 & $(975,1.071)$ \\
\hline
\end{tabular}

with the unlouded beads (mean $=690, S D=180$ ) and untreated cochleas (mean $=770, S D=190$ ). $\mathrm{A}$ significantly higher SGN density difference was also observed in the intracochlear NT-3 loaded bead group (mean $=980, \mathrm{SD}=210$ ) compared with the unloaded beads $(p<0.001$, mean $=700, S D=250)$ and untreated cochleas $($ mean $=770, S D=190)($ Fig. 2$)$.

\section{Effect of Beads on Individual Cochlear Turns}

Individual cochlear turn auditory norve density comparisons were made for round window and intracochlear bead implantations. For both methods of bead delivery, there was significantly higher SGN protection in the treated ear through all the coxthlear turns $(p<0.001)$; however. there was no difference noted between the turns (Fig. 3). Although in the intracochlcar test group there was a trend toward greater protection in the lower turns. this was not significant.

\section{DISCUSSION}

This investigation established alginate beads to be an effective delivery vehicle for NT.3. The in vitrs studies demonstrated that alginate encapsulates a large percentage

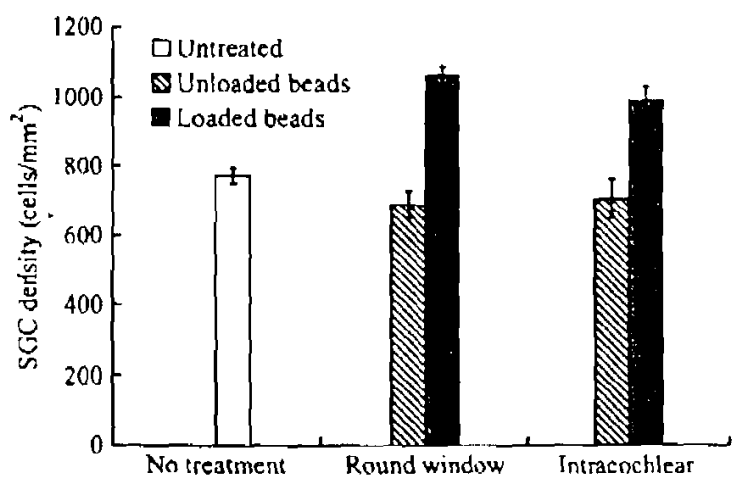

FIG. 2. Comparison of round window and intracochlear methods of baad implantation. Alginate beads loaded either with a control solution (unloaded beads) or with NT-3 (loaded beads) were implanted either onto the round window membrane of deafened guinea pigs or within the basal turn of the cochlea (intracochlear) NT-3 loaded beads implanted at both sites were effective in maintaining the survival of SGNs compared with unloaded beads or cochleae that received no treatment. Error bars represent standard error of the mean. 

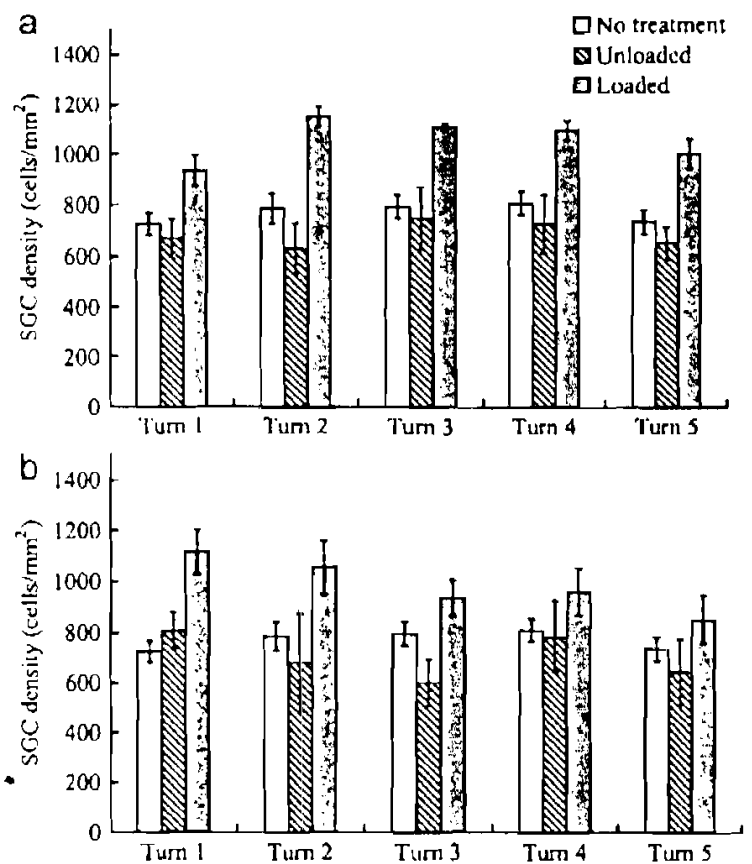

FIG. 3. SGN density in each turn of the cochlea after round window and intracochlear alginate bead implantation. NT-3 loaded or unloaded beads were implanted at the round window $(A)$ or within the basal turn of the cochlea $(B)$ of deafened guinea pigs for 28 days. SGN density was measured at each turn of the cochiea. NT.3 loaded beads demonstrated greater survival of SGNs through all the cochlear turns compared with unioaded beads or untreated cochleae. For the intracochlear implantalions, this effect was most prominent in the basal turns of the cochlea. Error bars represent standard error of the mean.

of NT-3. in the vicinity of $98 \%$ 10 $99 \%$, and the addition of heparin favorably altered the release kinetics 10 a slower and sleadier relcase over 5 day's (Fig. 1). This may potentially reduce the toxicity that could be associated with a large initial NT relcase from alginate.

The amount of NT-3 released in vitro $(0.33 \%$ of initial uptakc) was significantly less compared with its uptake. One possible explanation is that the beads have not yet fully degraded by the end of the release study and that $\mathrm{NI}^{-3}$ is still present within the bead. If so, the potential NT-3 deliverable by the bead cxceeds that shown from our release studies, and delivery may depend on the rate of degradation in different environments. Another possible explanation is that NT-3 may be bound to alginate breakdown products and not freely available for LLISA measurements. This is suspected because when the beads were degraded in a calcium-chelating environment of ethylenediaminetetraacetic acid to quantify the initial uplake of NT-3, the mcasured amount was $0.33 \%$, considerably less than the $96 \%$ anticipated.

The in vivo work has demonstrated the alginateheparin beads to be an effective delivery vehicle for NT3, with a significant protective effect upon the auditory nerve. Thic protective effect was measured as an increase in the demsity of surviving spiral ganglion cells, although the protection was not complete because treated animals had poorer spiral ganglion cell survival than normal controls.

Other protective effects that may be achieved by administration of NTs includc an increase in soma size (40) and preservation or resprouting of peripheral dendrites (41). Functional effects of NTs include a reducrion in the threshold of electrically evoked auditory brainstem potentials $(42,43)$. Therefore, there may be benefits in delivering NT's to cochlear implant recipients, both in terms of neuronal survival and function. The current study provides a model for the development of a clinically applicable delivery method.

Although in this study the alginate beads were used in deafened animals, it is anticipated that they may have a role in drug delivery to the hearing ear. Alginate could potentially impact upon hearing by exerting toxic effects upon the inner ear or alternatively by causing a conduclive hearing loss when an alginate bead is placed upon the round window. The latter should be temporary. and resolve when the bead degrades. Further investigation is required to explore the effects of alginate upon hearing.

This investigation has demonstrated several polentially important advantages of the delivery vehicle. First. alginate-heparin beads are nontoxic to ncurons becaluse there was no significant difference in SCiN densitics between cochleae implanted with unloaded beads and the unlreated ears (Figs. 2 and 3). Second, the beads are biodegradable. They were found to degralded into a gelatinous scmiformed paste afler 4 weeks in vivo. Third, the NT-3 loaded beads are efficacious in promoting neural survival when applied either to the round window or the basal turn of the cochlea (Figs. 2 and 3). This protection was universal for all the turns of the cochlea (Fig. 3). Although the protection from the ototoxic insult was not complete, with further refinements of the delivery system, we may be able to a provide greater degree of release and protection. Such neuronal protection demonstratce by NT-3 loaded alginate-heparin beads could be applied to other areas of nerve regencration research such as in the spinal cord and peripheral nerves (4t).

Finally, this preliminary study has demonstrated that round window and intra-cochlear application of algirate-heparin beads are equally efficacious in delivering NT-3 to the cochlea (Figs, 2 and 3). The tound window route maly have potential clinical applications in delivering drugss. NTs, and viral vectors in a simple outpaticnt setting under local anesthesia. Snall beads could be manufactured, loaded with drugs. and delivered to the round window by way of a tympanotomy performed under local anesthesia. Although not directly applicable in clinical settings. the intracochlear routc demonstrated that NT-3 release from a polymer-coated cochlear implant electrode is feasible. This opens up the potential for the delivery of drugs that are impermeable (o) the round window or even stem cell delivery to the cochlea. The curtent study is the first to demonstratc efficacious NT delivery bound to a polymer placed adjacent to, or within, the inner ear. 
Acknowledgments: The authors thank Maria Clarke. Prudence Nielsen, and Michacl Birch for their help and tcclinical expertisc.

\section{REFERENCES}

1. Minor I.B. Intratympanic gentamicin for eontrol of vertign in Menières dinease: vestibular signs that specify completion of therapy. Am J Otol 1990:20:209-19

2. Kassinco S, Pyykko I, Ishizaki ll. at al. Intratympanic gentamicin in Meniere's disease. Actr Otohayngol 1998:118:294-8.

3. HolTer Mt: Kopke RD, Weisskopf P, a al. Usc of the round window microkatheter in the treatment of Menjère's disease. laryngoscope 2001:111:2046-9.

4. Hoffer ML: Kopke RD, Weisskopf P, et al. Microdose gentamicin adrninistration via the round window microwathetcr: resules in pa-

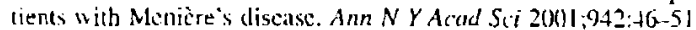

5. Yang GS. Song HT, keithlcy EM, et al. Intratympanic immunosuppressives for prevention of immune-mediated sensonineural

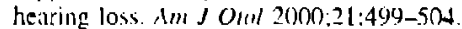

6. Kupke RD. Hoffer ME, Wester D, et al. Targeted topical steroid therapy in sudden scnsorineural heuring loss. Onol Neturom 2001 22:475-9.

7. Gianoli GiJ. Li JC. Transtympuinic steroids for treatuncu of sudden hearing loss. Otolaryngol Head Nock Sirg 2001;125:142-6.

4. Silverstein H. Arruda J, Rosenberg Sl, el al. Direct round window membrane applicution of gentamicin in the treatment of Menière disease. Oholarngol Head Neck Sirg 1999:120:649).55.

9. Pasic TR. Rubel LW. Rapid changes in cochliar nucleus cell si/e folluwing blockade of anditory nerve electrical aterivity in gerbils $J$ Comm liamol 1989:283:47480.

10. Jackion LF. Silversecin $H$. Chemicul perfusion of the inner ear. Orolunwer Clin North An 2002;35:639-53.

11. Brown IN. Ifiller JM, Altschuler RA, et al. Osmotic pump inplant for chronic infucion of drugs into the inncr car. Hear Res 1993:70: $167-72$.

12. Schindler JS. Schindler RA. Neurotrophin action in the tochlea: implications for cochlear implants. Ad Otorhinelarygugal 1997:52 $8-14$.

13. Frnfors P. Duan MLL. LiShamy WN. et al. Protection of anditory neurons trom aminoglycoside ioxicity by neurotrophin-3. Nar . Had 199)(6:2:46:3-7

4. Narir TS. Prienkorn DM, Miller JM, et al. In livo binding and hearing lous afler intracoclalear infusion of KHRl-3 antibods. $/ c^{2}$ Re's 1997:107:93-101.

15. Lalwami AK. Han JJ. Walsh BJ. el al. Green tluoreseent protein iss a reporter for gene ramser studies in the enchlos. Hear Res 1997 $11+1.39-17$.

16. Gombots WR. Wae. SF. Protein release from alginate matricen. Ad. Dris $D^{\prime} / R^{\prime} \cdot 1998: 31: 267-85$.

17. EJthlan ER. Mathiowitz E. J anger R. el al. Controlled and modulated relcase of hasic tihrohlitit growth liuctor. Biomaterials $109 ! 12.619-26$.

18. Lahim RI, Scilhio FW, Liklman FR, at al. Lacial periviscular delivery of hasic fibrublast growth factor in patients undergoing coromary bypass surgery: results of a phase I landomized. double. hind. placibo-controlled trial. Circularion 1999:100:1865-71.

19. Austin I. Bower JJ, kutek JB, et al. Controlled relcalse of leukutmia ithibitory factor (LIF) to tissues. Growth Factors 1997:15:61-8.

20. Maysinger D. Jitlsenjak I. Cuello AC. Micrnencapsulated nerse growth factor: effects on the forcbrain neurons following devascularizing cortical lesions. Netroseci Letl 1992;140:71-4.

21. Maysinger D), Kricklstein K. Filipovic-Creje J. et al. Micrococapsulated cilialy meurotrophic factor: physical properties and biologital activities. Exp Netures 1996;1.38:177-88.

22. Suzuki K. Regeneration of transected spinul eord in young idult rats using freezedried alginate gel. Nc'umrepont 1999;10:2891-t.

23. Kataoka K. Suzuki Y. Kitada M. cl al. Alginate. a bioresorbable matcrial derived from brown scaweed, conhances elongation of amputated axons of spinal cord in infant rats. I Biewned Mater Rt's $2001: 54 \cdot 37,3-84$

24. Sufan W. Suzuki Y. Tunihara M. el al. Sciatic nerve regeneration through alginate with tubulation or nontubulition repair in cat.

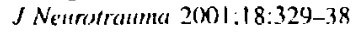

25. Sakiyama-Elben SE. Hubbell JA Controlied release of nerve growth factor from a heparin-contuining fibrin-based cell ingrowth matrix. $f$ Comtwol Rolease 2000):69:149.58

26. Sakiyama-Flbert SE. Hubbell JA. Development of librin derivitlives for controlled releuse of heparin-binding growth factore $J$ Commol Release 2000:65:389-40?

27. Tanihara M, Suzuki Y. Yamamoto E. el al. Sustained release of basic fibroblast growth factor and angingencsis in a novel covalently crosslinked gel of hepurin and alginale. I Biomed Mater Re's $2001 ; 56: 210-21$.

28. Stateker $H$, Liu W. Harnick C. et al. NT-3 combined with CNTl promotes survival of neurons in modiolus-spiral ganglion explants. Neurereport 1995:6:1533-7.

29. Yliknski I. rinola U. Virkkala J. el ul. Gujnea pig auditory neurons are protected hy glial coll line-derived growih factor from degenerition after noise trauma. Hear Res 1908:124:17 .26.

30. Zhene JF, Stewart RR. Gio WQ. Neurotrophin-t/s enhances survival of cultured spiral ganglion neurons and protects them Irom cisplatin neuruenxicity: $J$ Nemosed 1995;15:5079-87.

31. Malgrange B, Lefebirs $P$. Van de Water TR. el al Fffects of neurolrophins on carly auditory neurones in call culture Neumreport 1996;7:913-7

32. Mut K. Ilunsbetger C.I.. Cleary J.Y. et al. Synergistic effecte uf BDNF: and NT-3 on postnatal spiral sanglion ncurons. $J$ Comp, Ne'urol 1997:386:529-39.

33. Markella PL. Clark GW. Shepherd RK, et al. Synergy betwern TGF-beta 3 and NT-3 to promole the survival of spiral ninglial nuturones in vitro. Aeirose; Lell 1998:240:77-80.

34. Marrellit PL. Gillespie LN, Clark G.M. et al. The neurotrophin uet synergistically with I.IF and memters of the TCF beta supertimily to promore the survisal of spiral ganglia neurens in vitro. Hear Res 14)9; 138:73-80

35. Cillespic LN. Clark Ginl. Barten PF. et al. LIF is more polent than BDNI: in promotine neurite outerow th of mammialian atuditory neurons in vitro. Aiturowern $2001: 12: 275-9$.

36. Sitlecker 11, Kophe R. Malgrange Bet al. NT-3 and/or BDNF therapy prevents loss of auditon neurons following low of hat cells. Nowrorepont 1996:7:889-94.

37. Miller JM, Chi DH. O'Keeffic LJ. el al. Selurotrophim t:an enhance spral ganglion cell urvisal after inner hair cell loss. III J Del Nombsci 1997;15:6.31-43.

38. Shephord RK. Clark GM. P'rogreaslse ototoxicity of neomycin nunilored using derived brainsem reiponse audionetry. Ilea $R^{\prime}$ ' 1985:18:105-10.

39. Hurdie NA. Shepherd RK. Sensornineural hearing loss dutin!: development morphological and forsiological responsc of the enchlea and aluditor brainstem. /liwe Rrs 1999:128:1+7-65.

40. Richardson R. OLeary SJ. Wiac t. et al. A Single Dore of Neuroerophin. 3 to the Coxhlea Sumounale Spiral Catunglion Neurom and Provides Trophic Support. Hoar Ro's 2005. In press.

4. Wise A, Richarduon R. Hardman J, et al. Resprouting and survival of guinea pig ecohleat neurons in re iponse w the administration of neurotrophins BDNF and NT-3. J Comp Neturol 2005. In press.

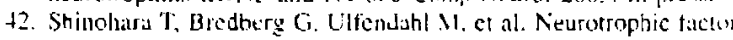
intervention restores auditory function in deafened amimals. Pror Nall Acad Sci lis A 2002:99:1657-60.

43. Shepherd R, Serrulo A. Lpp $S$ el al. Find Repont. NIII Commut

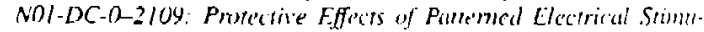
kation on the Deaf Auditory Sistem. Vietoria. Austrula: Department of Otolaryngology. University of Whbourno. Parkills. 2003.

44. Olika M. Suzuki Y. Chou H. et a1. Novel heparin/itginate gel combined with balsic tihroblass grouth filctor promolem nerve ic gencration in rat cciatic neric. J Biomed Mater Res $2004 ; 7 ! \Lambda: 661-8$ 


\section{University Library}

\section{- M M N E R VA A gateway to Melbourne's research publications}

Minerva Access is the Institutional Repository of The University of Melbourne

Author/s:

Noushi, Fanoosh;Richardson, Rachael T.;Hardman, Jennifer;Clark, Graeme M.;O'LEARY, STEPHEN

Title:

Delivery of neurotrophin-3 to the cochlea using alginate beads

Date:

2005

Citation:

Noushi, F., Richardson, R. T., Hardman, J., Clark, G. M., \& O'Leary, S. (2005). Delivery of

neurotrophin-3 to the cochlea using alginate beads. Otology \& Neurotology, 26(3), 528-533.

Persistent Link:

http://hdl.handle.net/11343/27622 